\title{
The 16th International Geological Congress, Washington, 1933
}

U.S. Geological Survey, 950 National Center, Reston, VA 20192, USA; Email: cnelson@usgs.gov

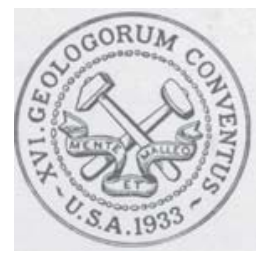

In 1933, the International Geological Congress (IGC) returned to the United States of America (USA) for its sixteenth meeting, forty-two years after the $5^{\text {th }} I G C$ convened in Washington. The Geological Society of America and the U.S. Geological Survey (USGS) supplied the major part of the required extra-registration funding after the effects of the Great Depression influenced the $72^{\text {nd }}$ U.S. Congress not to do so. A reported 1,182 persons or organizations, representing fifty-four countries, registered for the $16^{\text {th }} I G C$ and thirty-four countries sent 141 official delegates. Of the total number of registrants, 665 actually attended the meeting; 500 came from the USA; and fifteen had participated in the $5^{\text {th }} I G C$. The $16^{\text {th }}$ Meeting convened in the U.S. Chamber of Commerce Building from 22 to 29 July. The eighteen half-day scientific sections-orogenesis (four), major divisions of the Paleozoic (three), miscellaneous (three), batholiths and related intrusives (two), arid-region geomorphic processes and products (one), fossil man and contemporary faunas (one), geology of copper and other ore deposits (one), geology of petroleum (one), measuring geologic time (one), and zonal relations of metalliferous deposits (one)-included 166 papers, of which fifty (including several of the key contributions) appeared only by title. The Geological Society of Washington, the National Academy of Sciences, and the U.S. Bureau of Mines hosted or contributed to evening presentations or receptions. Twenty-eight of the $16^{\text {th }} I G C$ 's thirty new guidebooks and one new USGS Bulletin aided eight premeeting, seven during-meeting, and four post-meeting field trips of local, regional, or national scope. The remaining two new guidebooks outlined the USA's structural geology and its stratigraphic nomenclature. The $16^{\text {th }} I G C$ published a two-volume monograph on the world's copper resources (1935) and a two-volume report of its proceedings (1936).

\section{Prologue: The Invitation, 1929}

The Union (now Republic) of South Africa had hosted the $15^{\text {th }}$
IGC during 29 July-7 August 1929. One of the $15^{\text {th }}$ IGC Council's duties involved selecting the location for the next Congress. Article II of the IGC's statutes adopted at the $13^{\text {th }}$ IGC (Brussels, 1922) required Congresses to be held every three or four years.

When the $15^{\text {th }}$ IGC's Council held its fourth meeting at Pretoria on 5 August, General Secretary Arthur Hall (Assistant Director of the Geological Survey of South Africa [GSSA]) read letters of invitation from the Union of Soviet Socialist Republics (USSR) and the United States of America (USA) to host the $16^{\text {th }}$ IGC in 1932. In a letter dated 3 February 1928, Dimitri Mushketov, Director of the newly renamed All-Union Geological Committee at Leningrad (the former and future St Petersburg), and Mikhail Tetiaev, the Committee's Secretary General, described to the $15^{\text {th }}$ IGC's Committee of Organization the "immense progress" made in understanding the geology of all the Russias since the $7^{\text {th }}$ IGC held in St Petersburg in 1897 (Hall, 1930, p. 130). Charles Berkey (Columbia University), the Secretary of the Geological Society of America (GSA) since 1922, submitted an alternative request, supported by Charles Dawes, Vice President of the USA, in a letter of 21 June 1928 from the USA's ambassador to the Court of St James. They asked the Secretary of State for Foreign Affairs to transmit to the $15^{\text {th }}$ IGC's President, Arthur Rogers (Director, GSSA), the offer, from the Chairman of GSA's Continuing Committee on Invitation and Organization of the IGC to the USA's Secretary of State Frank Kellogg, to hold the $16^{\text {th }}$ IGC in the U.S. "under the auspices of the United States Government" (ibid., p. 131). The invitation from the USA, Berkey emphasized, "was as near a final one from the Government as was possible to obtain at this juncture" (ibid.). Berkey asked the Council's fifty-nine members present at the fourth meeting to consider it official. Bailey Willis (Stanford) seconded Berkey's motion and it passed "on a show of hands". Twenty-three members of the Council supported the USSR's offer while thirty-three voted to accept the USA's invitation (ibid.).

\section{Planning and Financing, 1930-1932}

The USA, as host for the $16^{\text {th }}$ IGC, would, of course, have to find ways and means to pay for it. Initial discussions began within the GSA, for since 1891 it had been the organization that provided liaison and assistance for U.S. participation in the IGCs. Securing Federal funds, the U.S. organizers thought, would be easy because the USA's economy had continued to prosper through the 1920s, and, on 4 March 1929, the Republican Herbert Hoover succeeded Calvin Coolidge as the USA's $31^{\text {st }}$ President. Hoover had assisted Waldemar Lindgren's U.S. Geological Survey (USGS) team in the Sierra Nevada while earning a BSc in geology at Stanford in 1895. Hoover, subsequently a successful mining entrepreneur and World War I humanitarian, also served as Secretary of Commerce (1921-1929) in the administrations of Republicans Warren Harding and Coolidge. In the national election 
of 1928, Hoover swamped his Democratic opponent and the Republicans increased their majorities in the House of Representatives and in the Senate. Hoover took his oath of office on 4 March 1929, one day after the $50^{\text {th }}$ anniversary of the USGS' founding. He invited the USGS staff to a luncheon at the White House on 21 March to honor the agency's anniversary. The gathering was recorded in a group photograph taken on the grounds just outside the Rose Garden, where President Hoover, Secretary of the Interior Ray Wilbur, and USGS Director George Smith stood front and center. Hoover appointed Dawes ambassador to Britain, and he confirmed his predecessor's decision about the $16^{\text {th }}$ IGC. Hoover agreed to serve as Honorary President.

However, neither of Hoover's twin presidencies nor funding for the $16^{\text {th }}$ IGC proved easy. The USA, as a creditor nation, increased its gold reserves during the 1920s. Coolidge's administration continued a low-interest policy that failed to stem the specie flow and fuelled speculation in gold and other stocks, whose prices continued to rise after Hoover took office and into most of the summer of 1929. USA stocks declined in September and crashed heavily in October. By mid-November, as the financial panic continued, Wall Street's listed stocks had lost nearly US\$30 billion in market value. As is well known, the effects from the burst bubble began to ripple through the national and global economies (see Fausold, 1984; Garraty, 1986; and Kennedy, 1999).

By the spring of 1930, as the American economic recession deepened, the GSA had arranged with the USGS to convene the $16^{\text {th }}$ IGC in Washington in June 1932, accompanied by excursions in May, and others in June through early July, to take advantage of cooler weather and lower travel rates than those expected in Washington later in the summer. Walter Mendenhall (see Figure 1), who had joined the USGS in 1896 and worked in its geologic and groundwaterresources units before managing its Land Classification Board for a decade and then becoming Chief Geologist in 1922, agreed to serve as the $16^{\text {th }}$ IGC's General Secretary. Henry Ferguson (USGS), who helped the U.S. Bureau of Mines (USBM) to prepare the USA's portion

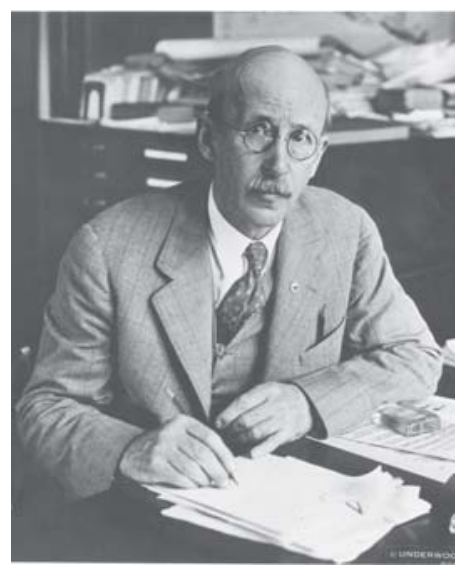

Figure 1. Walter Curran Mendenhall (1871-1957) in 1930; Director, USGS (1930-1943); NAS, 1932; General Secretary, $16^{\text {th }}$ IGC (Library of Congress).

of the $15^{\text {th }}$ IGC's report on the world's gold resources, chaired the Excursion Committee, whose members, and their colleagues from academia, government, and industry elsewhere in the USA, began preparing guidebooks. In October 1929, Mendenhall had called for greater support for basic geologic research in the USGS. "To apply science to human needs", Mendenhall asserted, "there must be science to apply. Research cannot be neglected in any field of science, geologic or other", he continued, "without jeopardizing its usefulness" (Mendenhall, 1929, p. 12). Funds from the USGS' new line-item of US\$100,000 for "fundamental research in geologic science" (U.S. Statutes at Large, v. 46, p. 311, 14 May 1930), gained for the fiscal year 1930-1931, supported work by USGS geologists toward completing their contributions to the guidebooks, a new geologic map of the United States, and those of several of its States.

The $16^{\text {th }}$ IGC's Committee on Organization, likewise selected under the 1913 rules, comprised Hoover and twenty-nine Members from academia, industry, and State and National governments. Lindgren (see Figure 2), USGS Chief Geologist during 1911-1912 and subsequently Rogers Professor of Geology at MIT, served as Chairman. Mendenhall (General Secretary), Ferguson and the USGS geologist Marcus Goldman (Assistant Secretaries), Edward Mathews (Johns Hopkins and General Treasurer), Olive Postley (USGS and

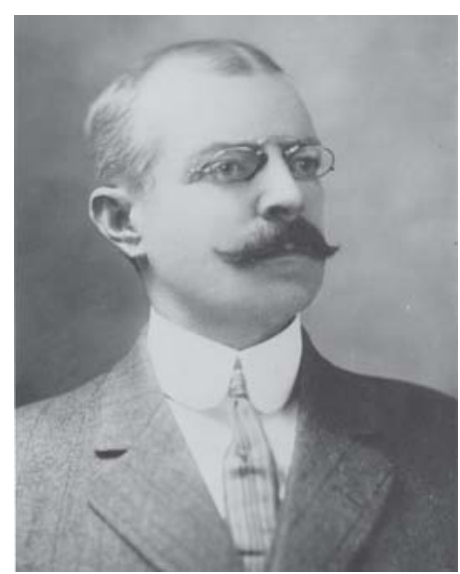

Figure 2. Waldemar Lindgren (1860-1939) in 1912; NAS, 1909; President, $16^{\text {th }}$ IGC (Library of Congress).

Administrative Assistant), and Raymond Becker (Business Manager) joined Hoover and Lindgren as $16^{\text {th }}$ IGC officers. The Organization Committee also included Foster Bain (Secretary of the American Institute of Mining and Metallurgical Engineers [AIMME]), Alan Bateman (Yale), Berkey, Eliot Blackwelder (Stanford), Isaiah Bowman (Director of the American Geographical Society, but later at Johns Hopkins University), Reginald Daly (Harvard), Arthur Day (Carnegie Institution Geophysical Laboratory), Everette DeGolyer (Amerada Petroleum), Arthur Keith (USGS), Andrew Lawson (Berkeley), Charles Leith (University of Wisconsin), Richard Penrose, Jr (Philadelphia), Sidney Powers (Tulsa), Wallace Pratt (Director, Humble Oil), William Wrather (Dallas), and David White (USGS: Chief Geologist, 1912-1922). The organizers appointed a six-person Executive Committee consisting of Bain, Berkey, DeGolyer, Lindgren, Mathews, Mendenhall, and White.

The Organization Committee's First Circular, issued in September 1930, listed program topics and field trips proposed for consideration by prospective attendees. To add to the list of world mineral resources-iron, coal, and gold-already discussed at recent IGCs and treated monographically as part of their reports, the $16^{\text {th }}$ IGC's organizers selected petroleum and established a Petroleum Committee to join the existing Excursion, Finance, and Program groups. The Program Committee solicited comments and offers of papers on ten 
proposed subjects also of current interest. The Excursion Committee proposed offering seven trips before the sessions in Washington, several during the meeting, and four after the sessions. But two months later, in the USA's mid-term elections, the Republicans lost control of the House of Representatives and maintained only a one-seat margin in the Senate.

In December 1930, Mendenhall succeeded Smith as Acting Director of the USGS, after Hoover nominated Smith as Chairman of the Federal Power Commission. On 29 December, Mendenhall reported the additional progress made by the $16^{\text {th }}$ IGC's organizers to the annual meeting of the GSA in Toronto. As national governments had financially supported recent IGCs, the Secretariat had "explored the possibility of securing [U.S.] Government grants for administrative expenses of the $\left[16^{\text {th }}\right]$ Congress and the publication of its proceedings" (Mendenhall, 1931, p. 178). The USGS sought from the $71^{\text {st }}$ U.S. Congress approval of a House joint resolution intended to provide during fiscal 1931-1932 funds from the Interior Department to publish the guidebooks and the national geologic map, and money from State Department for administrative expenses and publishing the meeting's report and its petroleum monograph.

By the time the Second Circular appeared on 1 August 1931, the effects of the growing worldwide economic depression, the failure to pass the joint resolution on finances, and responses to the First Circular convinced the Organization Committee, now expanded to thirty-two members, to postpone the start of the $16^{\text {th }}$ IGC until late June 1933. The Committee now specified seven principal topics for discussionarid-region geomorphology, batholiths and related intrusives, fossil man and contemporary faunas, measuring geologic time, orogenesis, the Paleozoic's major divisions, and zonal relations of metalliferous deposits. These were selected "as especially important at this time" and papers invited for them (Mendenhall, 1933, p. 247). The Excursion Committee also planned nine pre-meeting excursions (eight between the Mississippi Valley and the Atlantic Coastal Plain and one from San Francisco to Washington), eight more near and in Washington during the sessions, and five post-meeting trips. The last group included two transcontinental excursions (one with optional sidetrips and the other providing a general cross-section of U.S. geology), and one each on the glacial geology of the central states, Lake Superior metals deposits, and (by air) geomorphological features between Washington and San Francisco.

While planning continued in December 1931, the $72^{\text {nd }}$ U.S. Congress reconsidered the Organization Committee's request for Federal financial support and the Senate confirmed Mendenhall as the USGS' fifth Director (see Rabbitt, 1986). Hoover and his Secretary of State Henry Stimson asked the legislators to approve the joint resolution reintroduced in the House, provide US $\$ 85,000$ for the $16^{\text {th }}$ IGC's expenses, and make US $\$ 35,000$ of that sum available during fiscal 1932-1933. The anticipated US\$240,000 required for the fourteen pre- and post-meeting excursions, would "be raised by the geological congress and its friends" (U.S. Congress, 1932a, p. 3). The remaining US\$50,000 from the appropriation would be used during fiscal 1933-1934 to print and issue the $16^{\text {th }}$ IGC's reports. Although Bowman, Day, Mendenhall, and Smith testified in hearings held by the House Committee on Foreign Affairs during FebruaryMarch 1932 (U.S. Congress, 1932b), the legislators decided against giving Federal monetary support to the $16^{\text {th }}$ IGC.

The GSA rescued the $16^{\text {th }}$ IGC from further postponement or termination by supplying funds from its new Penrose Bequest. Richard Penrose, Jr, like Hoover a successful mining entrepreneur, had died in July 1931. His will, reflecting the advice he sought from Berkey and other colleagues, divided most of his estate of US\$10 million equally between the American Philosophical Society and the GSA. In July 1932, GSA's Council decided to support the $16^{\text {th }}$ IGC by donating "the income from Penrose's investments" accrued before his estate was settled (Eckel, 1982, p. 26). GSA's new Advisory Committee on Policies and Projects—Leith (Chairman), Frank Adams (McGill), Bowman, Rollin Chamberlin (University of Chicago), Morris Leighton (Illinois State Geologist), Lindgren, and John Reeside, Jr (USGS) - coevally decided, as one of a dozen recommendations, against aiding IGCs and other scientific meetings, except for the $16^{\text {th }}$ IGC, as "probably never again financially feasible" (ibid., p. 27). The GSA's Council intended the US $\$ 90,000$ grant to the $16^{\text {th }}$ IGC "as further evidence of good will and co-operation in the advancement of the science" (Fairbanks and Berkey, 1952, p. 764). Although on 22 April the USGS saw its line-item funds for fundamental research in geology reduced from US $\$ 100,000$ to US $\$ 40,000$ for fiscal 1932-1933, the agency took US\$50,000 from its US $\$ 110,000$ appropriation for engraving and printing geologic and topographic maps during that year and directed it toward the cost of publishing the new geologic map of the United States. The American Association of Petroleum Geologists (AAPG) contributed an additional US $\$ 1,000$.

The Third and Fourth Circulars, issued on 1 December 1932 and 1 May 1933, finalized the arrangements for the $16^{\text {th }}$ IGC. During 8 22 July participants could register for US\$5 at the GSA House on Columbia's campus in New York City (NYC), the California Division of Mines office in San Francisco's Ferry Building, or at the U.S. Chamber of Commerce Building (CCB, 1925; see Figure 3) at 1615 H Street, N.W., in Washington, just north of Lafayette Square (now Park) and the White House, and just east of Connecticut Avenue. The CCB also was within four blocks to the southwest of the USGS offices in the Interior Department Building (1917; now the General Services Administration), at $18^{\text {th }}$ and F Streets. The circulars also invited attendees to participate in the meetings of four other scientific organizations-the Pan-Pacific Science Congress (Vancouver, Canada, 1-22 June), the American Association for the Advancement of Science (Chicago, 19-24 June), the AIMME (Chicago, 26-29 June), and the Society of Economic Geologists (Princeton, 7-8 July).

Twelve brief trips within NYC and to nearby locales, and the longer A-series of pre-meeting excursions from NYC and Washington, would occupy 6-20 July. The GSA House planned to serve afternoon

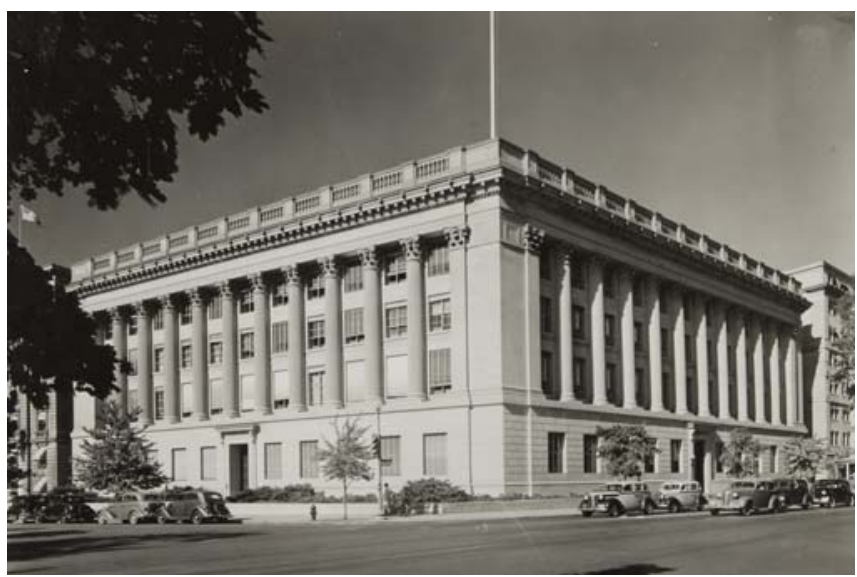

Figure 3. U.S. Chamber of Commerce (Chamber of Commerce). 
tea daily and the American Museum of Natural History (AMNH) arranged to host a reception to honor the foreign guests on $21 \mathrm{July}$. Interested attendees could then use the printed guide when visiting the city's AIMME, the American Geographical Society, and its other scientific institutions before returning to the special-rate Taft (at $7^{\text {th }}$ Avenue and $15^{\text {th }}$ Street) or other hotels. They would leave by train for Washington at 6 p.m., at the two-thirds fare arranged by the Organization Committee for all rail (but not steamship) travel to and from the IGC. The general sessions and volunteered exhibits at Washington would begin at the $\mathrm{CCB}$ on the following day and continue through 29 July. The topics for discussion now included the original seven plus petroleum geology, after the Organization Committee selected copper as the subject for the $16^{\text {th }}$ IGC's commodity volume and invited experts to send papers for evaluation by a separate committee chaired by consulting engineer Arthur Notman (NYC). Prospective authors for the general sessions were asked to submit abstracts (200 words maximum) of their papers to the General Secretary by 1 June and full typescripts (5,000 words maximum and ready for publication) by 1 July. All attending and non-attending registrants would receive the list of registrants, the program, the abstracts of papers, guides to the scientific institutions of NYC and Washington, the thirty IGC-excursion guidebooks, the new, four-sheet "Geologic Map of the United States" $(1: 2,500,000)$ by George Stose and Olaf Ljungstedt (USGS), and the final report. The Organization Committee also noted the deaths of three members-Penrose, Powers, and Benjamin Emerson (Smith College and USGS) — and the addition of Notman and James Dunn (State Department's International Conference Division).

\section{Registration}

By the time the $16^{\text {th }}$ IGC met in July 1933, the American people had rejected Hoover and his failed policies, which favored loans to businesses rather than public-work projects, and elected Franklin Roosevelt as their new President. Roosevelt took office in January 1933, began work on the USA's economic and social recovery during his administration's first "Hundred Days" (see McJimsey, 2000), and joined Hoover as an Honorary President of the $16^{\text {th }}$ IGC. Lindgren, Mendenhall, Mathews, Ferguson, Goldman, Postley, and Becker continued as $16^{\text {th }}$ IGC officers. Berkey (Chair), DeGolyer (Secretary), Ferguson (Treasurer), Bain, and David White served as the Executive Committee of the now 32-member Organization Committee.

A reported 1,182 persons and organizations registered for the $16^{\text {th }}$ IGC, the largest number yet recorded. They represented fiftyfour countries and thirty-four of these nations sent 141 official delegates. Although only 665 of the members actually came to Washington, they formed the third highest total after those at the $14^{\text {th }}$ IGC (Madrid, 1926) and the $7^{\text {th }}$ IGC (St Petersburg, 1897). Five hundred persons from the USA came to the $16^{\text {th }}$ IGC. Fifteen of the participants also attended the $5^{\text {th }}$ IGC (see Nelson, 2006) Adams, Charles Barrois (Lille), Whitman Cross (USGS and one of the Assistant Secretaries in 1891), Darton, Gerhard de Geer (Stockholm), Keith, Charles Keyes (Des Moines and Tucson), Alfred Lane (Tufts College), Lawson, Emmanuel de Margerie (Paris), Ezequiel Ordoñez (Mexico City), Timothy Stanton (USGS Chief Geologist since 1930), Edward Ulrich (U.S. National Museum and ex-USGS), David White, and Willis. Attendees at the $16^{\text {th }}$ IGC, as at the $5^{\text {th }}$ and other IGCs, represented a mix of aspiring as well as established geologists.

\section{Accommodation and Communications}

The Organization Committee secured special rates (on the European plan, with baths) for attendees at the Shoreham (now the Omni Shoreham) Hotel, the Meeting's headquarters. The Shoreham, at 2500 Calvert Street, N.W., just west of Connecticut Avenue, was about 2.7 kilometers northwest of the Chamber of Commerce Building, but could easily be reached by streetcar or taxi service. The Shoreham charged US $\$ 4$ for a double (two-bed) room and US $\$ 3$ for single-bed accommodation. The organizers expected that meals there and at other hotels or at restaurants in Washington would require less than US\$2-\$3 per day. The Committee asked that mail and telegrams for members of the $16^{\text {th }}$ IGC be sent to the addresses in NYC, San Francisco, or Washington, but they also established "Intergeol Washington" for all cable and radio messages.

\section{Opening Sessions}

The Council's membership, specified by Article IX, included (no more than) six representatives from the Organization CommitteeBain, Berkeley, Blackwelder, Henry Kümmel (New Jersey State Geologist), Frederick Ransome (CalTech and ex-USGS), and David White-plus official delegates (from national governments and academies, and directors of national surveys and university institutions), and selectees (Charles Wright [the American Vice-Consul in Rome], Arthur Smith Woodward [Sussex and ex-British Museum of Natural History], B. P. Nekrasov, Dimitri Perkin, and Nikolai Svitalsky [all from the USSR's newly renamed All-Union Geological Exploration Administration], Ferguson, Goldman, and Mathews). The Council met initially at 9.30 a.m. on Saturday, 22 July, and each weekday thereafter at $9.40 \mathrm{a} . \mathrm{m}$. As before, the Council approved the Officers (Bureau), including as Vice Presidents all government delegates. The opening meeting of the General Assembly followed at 11.00 a.m. on the 22nd. There, Past General Secretary Hall (representing Past President Rogers), U.S. Secretary of the Interior Harold Ickes, President Lindgren, GSA President Leith, and General Secretary Mendenhall welcomed the attendees and wished them a successful meeting. Lindgren, remarking on the day's heat and humidity, advised them follow the Roman practice of making haste slowly.

\section{Scientific Sessions}

The eighteen half-day scientific sections at the Chamber of Commerce Building comprised from one to four sequences of selected formal papers and discussions held at 10.00 a.m. each morning and 2.00 p.m. each afternoon. Ten of the sections ran concurrently in pairs to accommodate the 116 selected presentations; another fifty papers were given only by title. Presenters invited to speak for fifteen to twenty minutes received ten additional minutes for discussion; those limited to five or ten minutes were allocated five minutes of discussion.

Concurrent sections in the afternoon of 22 July evaluated Appalachian orogenesis and measuring geologic time. Franz Eduard Suess (Vienna) compared mountain systems in Europe and North America. Hans Stille (University of Berlin) contrasted tectonic regimes on those continents. And Arthur Bevan (Director, Virginia Geological Survey) and three other U.S. geologists described structures and times of orogeny in the northern and central Appalachians. Alfred Lane's 
(MIT) "Rating the Geologic Clock," began the section on measuring geologic time, to which Wilbur Foye (Wesleyan College), Jakob Johannes Sederholm (Geological Commission of Finland), Keyes, and Ernst Antevs (Auburn, Maine) evaluated measurements and correlations in the Precambrian and the Quaternary. Among that section's six by-title papers were Gerard de Geer's review of international geochronology, Ebba de Geer's (Stockholm) "teleconnection of geochronology and historical time", Johann Koenigsberger's (Freiburg in Baden) discussion of remnant magnetism and time, and Iosef Starik's (Academy of Sciences, Moscow) assessment of the "lead method" of isotopic geochronology.

Two morning sections on 24 July treated fossil man and contemporary faunas and the geology of petroleum. In the former section, after Victor Madsen (Geological Survey of Denmark) reported the work of the IGC's Commission for the Study of Fossil Man, other colleagues reviewed human fossils and associated faunas on continents and individual countries-Arthur Smith Woodward for the "Old World," Louis de Lóczy (Hungarian Geological Survey) for Hungary, Raymond Dart (University of Witwatersrand) for southern Africa, and Davidson Black (Geological Survey of China, Peiping [Beijing]) for China. Smith Woodward proposed that humans originated in Tanganyika (now Tanzania) and subsequently spread to Britain, China, Java, and other parts of Eurasia. John Merriam (President, Carnegie Institution) organized and summarized papers by Chester Stock (CalTech), Barnum Brown (AMNH), and Edwin C. Eckel (Washington, D.C. and ex-USGS) about post-Pleistocene occurrences, principally at Folsom and other sites in the southwestern USA and in the Appalachians. Jorge Broggi (Lima), Ivan Gubkin (of the USSR's newly renamed All-Union Geological Exploration Administration), Irving Levorsen (Tulsa), Frank Clark (Mid-Kansas Oil and Gas), Tasia Stadnichenko (USGS), and Pratt discussed the tectonics, paleogeography, origin, and accumulation (in-place or migrant) of petroleum, but papers by Stanislav Zuber (Rome), Parker Trask (USGS), and Chitani Yoshinosuke (Imperial Geological Survey of Japan) on Ponto-Caspian occurrences, source beds, and Japan's petroleum appeared only by title. Pierre Teilhard de Chardin, SJ's (Geological Survey of China) evaluation of the "piedmont method" in continental geology led the afternoon's eight miscellaneous, but mostly paleontological, papers. This section's five by-title papers included Mushketov's review of Soviet glaciology since 1913 and a description by S. K. Girin, and four colleagues, of Soviet geophysicalprospecting methods.

On 25 July, the program devoted single morning and afternoon sections to batholiths and related intrusive bodies. Hans Cloos' (Bonn) discussion of pluton structure and orientation in relation to crustal movement began the morning's sequence of seven papers, which also included presentations on the origin and derivations of granites, and reports on intrusives in the Belgian Congo and Norway. In the afternoon, Arthur Buddington (Princeton), Joe Peoples (Wesleyan University), and Norman Bowen (Carnegie Geophysical Laboratory) reviewed batholiths, phacoliths, sills, and other intrusions in the Appalachians, Montana, and Idaho; and Arnold Heim (Zürich) evaluated batholiths in Tibet. Key contributions about mechanics and differential anatexis by Franc Loewinsson-Lessing (Academy of Sciences, Leningrad) and by Pentti Eskola (University of Helsinki) appeared only by title. The twelve oral papers in concurrent morning and afternoon sections evaluated stratal sequences, boundaries, biotas, and correlation (mostly by fossils rather than unconformities) of major divisions of the Lower and Middle portions of the Paleozoic Era in
Britain, Spain, Germany, Scandinavia, Japan, China, and North America by Otto Schindewolf (Prussian State Geological Survey, Berlin), Edward Ulrich (U.S. National Museum and ex-USGS), Kobayashi Teiichi (Tokyo Imperial University), Armand Renier (Director, Geological Survey of Belgium and University of Liège), Wilhelmus Jongmans (Netherlands Mines Bureau), Amadeus Grabau and Ting Ven King (Academia Sinica, Nanking [Nanjing]), and Raymond Moore (University of Kansas). Dimitri Nalivkin's (Mining Institute, Leningrad) overview of the Soviet Paleozoic formed one of three by-title contributions.

The sections on 26 July offered thirteen miscellaneous papers. The morning's initial three presentations discussed aspects of paleogeography, stratigraphy, and tectonics in Morocco, other French possessions (by the Ministry of Colonies' Henry Hubert), and Hungary (by Lóczy). This section continued with assessments of U.S. cryptovolcanic structures (by the University of Cincinnati's Walter Bucher), the role of bentonite-based correlations in the Ordovician of eastern North America, and how data from a 1932 earthquake in Nevada influenced ideas about the genesis of Basin-Range structure in western North America. Presentations during the afternoon focused on geologic maps. Stose reviewed his new map of the United States and Nelson Darton (USGS) discussed his in-progress revision of his coverage of the Washington area. Darton, with the late George Williams, had prepared a 1:62,500 geologic map of the Washington area for the $5^{\text {th }}$ IGC (Nelson, 2006, p. 284). This map, updated in cooperation with Keith, appeared as the "Historical Geology Sheet" in 1901 in the Washington Folio of the Geologic Atlas of the United States. The USGS published Darton's second revision on two sheets at 1:31,680 in 1947. Four European geologists then presented new coverage (at 1:500,000 to 1:2,000,000) of four parts of Africa-the Belgian (now Republic of) Congo, by Paul Fourmarier (Liège); Algeria, by Gaston Bétier (Algiers); Spanish Morocco (now Western Sahara), by Augustin Marin y Bertran de Lis (Madrid); and Eritrea, Somalia, and Ethiopia, by Giuseppe Stefanini (University of Pisa). Heim completed these reviews by discussing the 1932 geologic map of Switzerland, on four sheets, at 1:200,000.

Five papers in the third section on Paleozoic divisions, convened during the morning of 27 July, completed the review by analyzing the Upper Paleozoic. Arthur Walkom (Sydney) discussed the boundaries of the Permian in Australia; Alexander du Toit (Johannesburg) detailed the division of the Upper Paleozoic in Gondwanaland; Ting and Grabau assessed the Permian of China; David White described the American Permian; and Charles Schuchert (Yale) reviewed the correlation of "important" Permian sequences. The by-title papers included a summary of the Permo-Carboniferous in Australia, by William Edgeworth David (Sydney), and the Permian in the Urals, by biostratigrapher Georgii Fredericks.

The $16^{\text {th }}$ IGC's held its three remaining sections on orogenesiswith worldwide coverage of "crustal disturbance, regional correlations, and classifications of rock structures" (Mendenhall, 1933, p. 248)two on 27 July and the third during the morning of the $29^{\text {th }}$. Fourmarier proposed a rule of symmetry for the architecture of Earth's crust, Heim evaluated energy sources (solar, rotational, and axial) for the Earth's crustal movements, and Tokuda Sadazaku (Tokyo) analyzed three types of mountain arcs. But most of the papers treated topics in countries, regions, or single continents. Only Heim and Tokuda mentioned global continental drift as an overriding concept. "Even if we do not accept A. Wegner's theory in its entirety", Heim observed, "certain displacements accompanied by compression in one region 
and by extension in another, as well as the apparent differences in the amount of displacement in latitude and longitude of different continental blocks, can hardly be explained otherwise than by accepting the idea of continental drift, at least in a restricted sense" (Mendenhall, and others, 1936, p. 914).

On 15 November 1926, the AAPG had convened in NYC, as part of its annual meeting, a symposium on the theory of continental drift as proposed by Alfred Wegener. Published initially in an article in 1912, Wegener expanded his model in four German editions (19151929) of a book-length version, of which the third (1922) appeared in English and French in 1924. Willem van Waterschoot van der Gracht, a former Director of the Netherlands Geological Service, but then Vice President of Marland Oil, introduced and summarized a sequence of presentations about the model's viability by nine American and four European geologists. Frank Taylor (who had proposed his own concept of continental displacement in 1910) strongly favored drift, but six of the other Americans-including Chamberlin, Chester Longwell (Yale), Schuchert, and Willis-rejected Wegener's ideas principally for lack of a workable propelling mechanism. Wegener thought their objections unjustifiable, but the proceedings, published in 1928, continued to influence opinions in America (see Oreskes, 1999). The $16^{\text {th }}$ ICG's Program Committee invited Wegener to discuss his ideas of worldwide continental displacement at the meeting before they learned that he had died in November 1930 while returning from resupplying a scientific station on Greenland's ice-cap. Waterschoot van der Gracht, who might have tested opinion again in a larger international audience, left the USA in 1928 and became Director of the Netherlands Bureau of Mines in 1932. He submitted for the $16^{\text {th }}$ IGC's orogenesis sections only a by-title analysis of the Late Paleozoic orogeny in North America.

While the second section on orogenesis convened in the afternoon of 27 July, a concurrent section discussed "geomorphogenic" processes and products in arid regions. Among its papers were Kenneth Sandford's (Oxford) analysis of the role of peneplains in the development of the Libyan Desert, Richard Russell's (Louisiana State University) analysis of the desert-rainfall factor in denudation, Nils Hõrner's (Geological Institute, Uppsala) description of physiographic processes on Central Asia's continental basins, Kirk Bryan's (Harvard) ideas about pediment formation, Blackwelder's "insolation" hypothesis of rock weathering, and George Barbour's (Geological Survey of China) discussion of China's loess. William Morris Davis' (Pasadena and ex-Harvard) views about desert "geomorphogeny" appeared only by title. While these two sections proceeded, other attendees met to form an "International Paleontologic Union", adopt a constitution and by-laws, appoint a ten-member organization committee (with Rudolf Richter [Frankfurt] as Chairman and Benjamin Howell [Princeton] as Secretary), and plan to meet at future IGCs.

Two additional sections, on the mornings of 27 and 29 July, evaluated the geology and zonal relations of copper and other metalliferous deposits. Their general papers included an analysis by William Emmons' (Director, Minnesota Geological Survey and Professor, University of Minnesota) of hypogene zoning in lodes, Svitalsky's views on zonal distribution of ore deposits, and Paul Niggli's (University of Zürich) by-title study of geochemistry as it related to this zoning. Five other presentations looked at zoning in specific mines and mining districts in North America and Europe. Teodoro Flores (Geological Institute of Mexico), Heim, Nekrasov, and Walter Weed (Scarsdale, NY) offered discussions of specific copper-ore districts in Mexico, Spain, the USSR, and the USA. The section closed with Jacques Thoreau's (Louvain) review of uranium ores from Shinkolobwe-Kasolo in the Belgian Congo's Katanga Province and Manuel Santellán's (Mexico City) twin presentations about beryllium and silver in Mexico.

\section{Commissions and Committees}

Ten International Commissions-Crust of the Earth, Distribution of the Karroo (Gondwana) System, Fossil Man (reestablished in 1929), Geologic Map of Africa, Geologic Map of Europe (1:500,000), Geologic Map of the World (1:5,000,000), Geophysics and Geothermics, Lexicon of Stratigraphy (volumes on Africa, America, Asia, Australasia, and Europe), Paleontologica Universalis, and Spendiarov Prize (see Milanovsky, 2004) - met during the $16^{\text {th }}$ IGC to report progress and plan future work. The Council agreed to discontinue the IGC's Commission on Glaciers in favor of the equivalent committee of the International Geophysical Union. The Council also approved the formation of a new Commission on Authors' Abstracts. On 26 July, the $16^{\text {th }}$ IGC's Spendiarov Committee_-John Flett (Chairman and Director, British Geological Survey), Hall, Gubkin, Matthews, and Stille-awarded its Prize, established during the $7^{\text {th }}$ IGC at St Petersburg in 1897 but given only four times since the initial award in 1903, to Thomas Nolan (USGS, see Figure 4) as the host country's most promising young geologist.

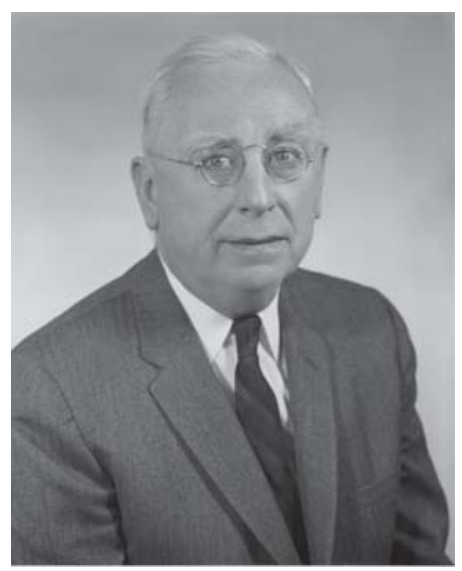

Figure 4. Thomas Brennan Nolan (1901-1992) in 1956; Spendiarov Prize, $16^{\text {th }}$ IGC; Assistant Director (1944-1956) and Director (19561965), USGS; NAS, 1951; Vice President, IUGS, 1964-1972 (USGS).

\section{Entertainment and Exhibits}

The Chamber of Commerce provided afternoon tea daily between 4.30 and 5.30 p.m. Most talks and other evening activities in Washington were held at the Shoreham. On 22 July, the Geological Society of Washington reception featured Douglas Johnson's (Columbia) "A Geomorphic Traverse of the United States", followed by a "smoker". Dr and Mrs Whitman Cross hosted an afternoon garden party on 23 July at their home near Connecticut Avenue and just north of Chevy Chase Circle. That evening, Hellmut de Terra (Yale) discussed his scientific exploration of the Himalayas and the Karakoram Mountains. The USBM screened its new film about the evolution of the oil industry on 24 July. For attendees not participating 
in Excursions B-5 and B-6, which departed on the evening of 25 July, Frank Adams (McGill) evaluated the importance of Charles Lyell's work on the $100^{\text {th }}$ anniversary of the publication of Volume III of his Principles of Geology. On 26 July, Victor van Straelen (Brussels) described the Albert National Park in the Belgian Congo. The NAS hosted on 27 July a reception for all attendees at its headquarters (1924) at $21^{\text {st }}$ Street and Constitution Avenue, N.W. The Regents and the Superintendent of Virginia's Mount Vernon received attendees at the home of General and President George Washington at 5.00 p.m. on 28 July.

Sixty-eight women-forty-three from the USA and twenty-five from other countries-registered for the $16^{\text {th }}$ IGC as members or accompanying members. In addition to Ebba de Geer's by-title paper, and Taisia Stadnichenko's presented paper, Florence Bascom (Smith and USGS), Winifred Goldring (New York State Museum), Anna Jonas (later Stose, USGS), and Eleanora Bliss Knopf (New Haven) co-authored four of the guidebooks. Julia Gardner (USGS), like Goldring, Jonas, and Knopf, one of Bascom's former students, also participated in the $16^{\text {th }}$ IGC. The American Association of University Women's National Club extended to all women attendees the privileges of its National Club House at 1634 I Street, N.W. Special sightseeing excursions for them, organized by the thirteenmember Women's Local Entertainment Committee, chaired by Mrs. Charles Wright, departed in private automobiles from the Shoreham during 24-28 July for tours of Arlington National Cemetery, the Folger Shakespeare Library, the Lincoln Memorial, the National Cathedral, the Pan American Union, the Washington Monument, and other sites of historical and cultural interest in the greater metropolitan area.

The Chamber of Commerce Building provided space for attendees and organizations to exhibit their publications and scientific specimens. The USGS displayed aspects of its operations and products at a site in the Interior Department Building near its offices.

On 27 July, at 12.30 p.m., 355 of the attendees assembled (by prior notice) around Lindgren and Mendenhall in the CCB's courtyard (since built over) for a group photograph. That image appeared as a folding plate, facing the key on page 54 of the $16^{\text {th }}$ IGC's Report (Mendenhall and others, 1936).

\section{Guidebooks for Field Trips}

The U.S Government Printing Office published (1932-1933) thirty guidebooks (G), to which 156 geologists contributed information, that aided nineteen local, regional, and national excursions by car, bus, rail, and (or) air before (A), during (B) and after (C) the meeting in Washington. Costs for these trips ranged from US\$5 to US\$360:
G1 / A-1:
G2 / A-2:
G3 / A-3:
G4 / A-4:
G5 / A-5:
G6 / A-6:
G7 / A-7:
G8 / A-8:
Eastern New York and Western New England Mining Districts of the Eastern States Southern Appalachian Region The Paleozoic Stratigraphy of New York Chesapeake Bay Region [Coastal Plain] Oklahoma and Texas [oil fields] Geomorphology of the Central Appalachians
G9: Mineral Deposits of New Jersey and Eastern Pennsylvania
G9: New York [City] and Vicinity New York [State] II

G10 / B-1,-2,-3: Southern Pennsylvania and Maryland [mines and structure]

G11 / B-4,-5,-6: Northern Virginia [geomorphology, stratigraphy, and structure]

G12 / B-7: $\quad$ Southern Maryland [Coastal Plain]

G13 / C-1: Western Texas and Carlsbad Caverns

G14 / C-1: Ore Deposits of the Southwest

G15 / C-1: $\quad$ Southern California

G16 / C-1; Middle California and Western Nevada

G17 / C-1: The Salt Lake Region

G18 / C-1, -2: Colorado Plateau Region

G19 / C-1: Colorado [State]

G20 / C-2: Pennsylvanian of the Northern Mid-Continent

G21 / C-2: Central Oregon

G22 / C-2: The Channeled Scabland

G23 / C-2: The Butte Mining District

G24 / C-2: Yellowstone-Beartooth-Big Horn Region

G25 / C-2: The Black Hills

G26 / C-3: Glacial Geology of the Central States

G27 / C-4: Lake Superior Region [copper and iron deposits]

G28: An Outline of the Structural Geology of the United States

G29: $\quad$ Stratigraphic Nomenclature in the United States

G30 / A-2, -6; The Baltimore \& Ohio Railroad (New York-

C-1, -2, -3, -4: Washington-Cumberland-Chicago or St. Louis)

Berkey chaired a committee that arranged the A Series of field trips and he led A-8. Ferguson oversaw the planning for the B and C Series and the publication of all the guidebooks. Of the two monthlong transcontinental excursions by special Pullman-equipped trains, Lindgren led C-1 and Richard Field (Princeton) led C-2. To further aid C-1, Darton (1933) prepared the sixth part—-the Southern Pacific's route from New Orleans to Los Angeles-of the Guidebook of the Western United States, a series of volumes about the geology and topography of other railroad routes to and along the West Coast that also appeared as USGS Bulletins during 1912-1922. Leighton led C-3 and Leith co-led C4. The $16^{\text {th }}$ IGC also published a guide to the scientific institutions of Washington, the latter to supplement three in-city excursions repeated each weekday-B-8a, the Smithsonian Institution, including the National Museum [1910]); B-8b, the National Bureau of Standards and the Carnegie Geophysical Laboratory and its Department of Terrestrial Magnetism; and B-8c, the Library of Congress, the Folger Shakespeare Library, and the Pan American Union.

\section{Invitation for the $17^{\text {th }}$ IGC}

On 24 July, during the Council's second meeting, Lindgren called for invitations for the next IGC. Gubkin, in renewing the USSR's offer in 1929, invited the IGC to hold its next meeting in Moscow or Leningrad. Flett, speaking for the British delegation, but unable to offer a firm invitation, asked for time to consult more widely about holding the meeting in London in 1936 to mark the $100^{\text {th }}$ anniversary of the BGS. When the Council met on 25 July, Mendenhall read Gubkin's letter of invitation. On July 28, the Council voted $32-0$ to accept the invitation of the USSR, then the only definite offer, to hold the $17^{\text {th }}$ IGC in Moscow. 


\section{Closing Session}

The General Assembly convened for its closing meeting during the afternoon of 28 July. Mendenhall read President Roosevelt's greeting and his hope that the meeting was "proving to be enjoyable and constructive" (Mendenhall, 1936, and others, p. 77). Flett, Sederholm, and Lindgren (the last in four languages) expressed their thanks to the organizers of the $16^{\text {th }}$ IGC, the USGS, and the GSA. Lindgren, "more than ever impressed with the value of contacts among geologists," said he was convinced that scientists were "working together harmoniously for the advancement of knowledge of this earth" (ibid., p. 92).

\section{Epilogue: Financial Summary and Final Report, 1936}

The $16^{\text {th }}$ IGC balanced its financial books. The meeting's receipts totaled US $\$ 151,122$, not counting the US $\$ 50,000$ the USGS provided for preparing and printing the guidebooks and the geologic map of the United States. In addition to the sums received from the GSA and the AAPG, the American Geographic Society sent US\$100 and individual donors gave US $\$ 2,885$, registrations and excursions brought in an additional US $\$ 51,294$, and publication sales, the Spendiarov Prize, and deposit interest yielded another US $\$ 5,843$. Disbursements of US $\$ 144,152$-US $\$ 10,733$ for administration, US\$79,175 for excursions, foreign guests, and meetings, US\$54,912 for publications, and US\$332 for the Spendiarov Prize and check tax-left a balance of US\$5,970 for the estimated bills payable as of 26 March 1936.

Mendenhall published an interim summary of the $16^{\text {th }}$ IGC in Science for 22 September 1933. The meeting issued its report on copper, edited by Notman's committee, in two volumes in 1935 . The $16^{\text {th }}$ IGC's two-volume Report appeared in 1936. It printed forty-five papers and forty-five abstracts, most being accompanied by illustrations, maps, discussions, and references. Since 1933, some authors had submitted papers to accompany their abstracts and others reduced their papers, already published elsewhere, to abstracts. The Report's second volume also contained the scientific reports of the IGC's Commissions, including those by Dart and other members of seventeen of the Commission on Fossil Man's twenty-four geographic subcommissions.

\section{References}

Darton, N. H., 1933, Guidebook of the Western United States-Part F, The Southern Pacific Lines, New Orleans to Los Angeles: U.S. Geological Survey Bulletin 845, 304 pp., 29 route maps $(1: 500,000)$. (The series also included USGS Bulletins, 611, 612, 613, 614, and 707.)

Eckel, E. B., 1982, The Geological Society of America-Life History of a Learned Society: Geological Society of America Memoir 155.
Fairbanks, H.R., and Berkey, C. P., 1952, Life and Letters of R. A. F. Penrose, Jr.: New York, Geological Society of America.

Fausold, M. L., 1984, The Presidency of Herbert C. Hoover: Lawrence, University Press of Kansas.

Garraty, J. A., 1986, The Great Depression-An Inquiry into the Causes, Course, and Consequences of the Worldwide Depression of the Nineteenthirties as Seen by Contemporaries and in the Light of History: New York, Harcourt Brace Jovanovich.

Hall, A. L., ed., 1930, Compte Rendue of the XV. Session. South Africa, 1929: Pretoria, Wallachs, v. 1.

Kennedy, D. M. 1999, Freedom from Fear-The American People in Depression and War, 1929-1945: New York, Oxford University Press.

McJimsey, George, 2000, The Presidency of Franklin Delano Roosevelt: Lawrence, University Press of Kansas.

Mendenhall, W. C., 1929, Geologic Branch, in Smith, G. O. Fiftieth Annual Report of the Director of the [U.S.] Geological Survey to the Secretary of the Interior: Washington, D.C., U.S. Government Printing Office, pp. 9-29.

Mendenhall, W. C., 1931, Announcement concerning Sixteenth International Geological Congress: Geological Society of America Bulletin, v. 42, pp. 177-179.

Mendenhall, W. C., 1933, The Sixteenth International Geological Congress: Science, v. 78, pp. 247-254.

Mendenhall, W. C. et.al., eds, 1936, International Geological CongressReport of the XVI Session, United States of America, 1933: Washington, D.C. [U.S. Government Printing Office], 2 v.

Milanovsky, E. E., 2004, Three sessions of the International Geological Congress held in Russia and the USSR [1897, 1937, 1984]: Episodes, v. 27, pp. 101-106.

Nelson, C. M., 2006, The Fifth International Geological Congress, Washington, 1891: Episodes, v. 29, pp. 279-286.

Nolan, T. B. and Siegrist, Marie, 1989, Recalling the $16^{\text {th }}$ IGC, Washington, 1933: Episodes, v. 10, pp. 329-331.

Notman, Arthur (Chair, Committee on Copper Volume), Bateman, A. M., Furness, J. W., Gilluly, James, Singewald, J. T. Jr, and Wright, C. W. eds, 1935, Copper Resources of the World: Washington, D.C. [Menasha, Wisconsin, George Banta], $2 \mathrm{v}$.

Oreskes, Naomi, 1999, The Rejection of Continental Drift-Theory and Method in American Earth Science: New York, Oxford University Press.

Rabbitt, M. C. 1986, Minerals, Lands, and Geology for the Common Defense and General Welfare-Volume 3, 1904-1939: Washington, D.C., U.S. Government Printing Office.

U.S. Congress, 1932a, International Geological Congress: U.S. Congress, $72^{\text {nd }}$, $1^{\text {st }}$ Session, House Report 801, 3 pp. (Serial 9492)

U.S. Congress, 1932b, International Geological Congress-Hearings [24 February; 1, 4, 15 March 1932] before the Committee on Foreign Affairs, House of Representatives, Seventy-second Congress, first session, on H. J. Res. 181, a joint resolution authorizing an appropriation for the expenses of the Sixteenth International Geological Congress, to be held in the United States in 1933: Washington, D.C., U.S. Government Printing Office.

Waterschoot van der Gracht, W. A. J. M. van, and others, 1928, Theory of Continental Drift-A Symposium on the Origin and Movement of Land Masses both Inter-continental and Intra-continental, as Proposed by Alfred Wegener: Tulsa, Oklahoma, American Association of Petroleum Geologists, and London, Thomas Murby. 